mean that a statistical search for homology will yield a proportion of comparisons which are not in accordance with any proposed pathway. The evolutionary pathway which we propose is based not only on the small number of base changes involved in each comparison but also on the minimal number of mutational events required to obtain the present day clupeines from the ancestral pentapeptide Ala-Arg-Arg-Arg-Arg.

We wish to acknowledge generous support by MRC and Fisheries Research Board of Canada.

J. A. BLACK

G. H. DiXoN

Department of Biochemistry,

University of British Columbia,

Vancouver, Canada.

Received June 19; revised July 24, 1967.

${ }^{1}$ Smithies, O., Connell, G. E., and Dixon, G. H., Nature, 196, 232 (1962).

${ }^{2}$ Eck, R. V., and Dayhoff, M. O., Science, 152, 363 (1966).

3 Cantor, C. R., and Jukes, T. H., Proc. US Nat. Acad. Sci., 56, 177 (1966).

${ }^{4}$ Fitch, W. M., J. Mol. Biol., 16, 17 (1966).

s Hill, R. L., Delaney, R., Fellows, R. E., and Lebovitz, H. E., Proe. US Nat. Acad. Sci., 56, 1762 (1966)

${ }^{\circ}$ Ando, T., and Suzuki, K., Biochim. Biophys. Acta, 121, 427 (1966).

'Ando, T., Iwai, K., Ishii, S., Azegami, M., and Nakahara, C., Biochim. Biophys. Acta, 56, 628 (1962).

${ }^{8}$ Ando, T., and Suzuki, K., Biochim. Biophys. Acta, 140, 375 (1967).

- Dixon, G. H., Essays in Biochemistry, 2, 147 (1966).

${ }^{\prime 0} \mathrm{~F}^{\prime} \mathrm{itch}, \mathrm{W} . \mathrm{M}$., and Margoliash, E., Science, 155, 279 (1967).

11 Fitch, W. M., J. Mol. Biol., 16, 9 (1966).

\section{Kinetics of RNA Labelling in Fractions enriched with Neuroglia and Neurones}

THERE are now methods of separating in bulk neuronal and neuroglial cells ${ }^{1,2}$, and we have used them to study the in vivo synthesis of RNA in these cellular fractions. There seem to be significant differences between the kinetics of labelling of the RNA of the two cell types.

6-14C-orotic acid $(\mathbf{4 4 . 5} \mathrm{mc}$./mmole) was given subarachnoidally to adult rabbits weighing 3-4 $\mathrm{kg}$ in a dose of $100 \mu \mathrm{c}$. in $0.2 \mathrm{ml}$. RNA was extracted with a mixture of sodium dodecyl sulphate and phenol at $4^{\circ}$, followed by re-extraction of the phenol phase and interphase at $45^{\circ} \mathrm{C}$, digested with DNase and analysed by centrifugation in 5-20 per cent sucrose gradients containing 0.1 molar sodium chloride and 4 molar urea (15 h at 20,000 r.p.m. in the $S W 25$ rotor of a Spinco ultracentrifuge at $\left.0^{\circ}-4^{\circ} \mathrm{C}\right)$. The results are summarized in Fig. 1.

One hour after the injection of the precursor neuronal RNA had a lower specific activity than neuroglial RNA, while after $3-6 \mathrm{~h}$ it was much more heavily labelled. These differences were more clearly seen in the cellular fractions prepared by the method of Satake and $\mathrm{Abe}^{2}$ (Fig. $1 a$ and $b$ ). Some of the most obvious differences were observed in the RNA fractions which sedimented before the $28 S$ peak. These fractions represent a mixture of pre-ribosomal components and of DNA-like nuclear RNA of unknown function ${ }^{3}$ which is synthesized more rapidly than the other types and is more rapidly degraded $^{4,5}$. The relative composition of neuronal RNA rich in the ribosomal species and of glial RNA rich in the nuclear components may be the basis of the different kinetics of labelling which we observed. Other explanations, however, cannot be excluded.

Fourteen hours after administration of labelled orotic acid the specific activity of neuronal RNA prepared by the method of Satake and $\mathbf{A b e}^{2}$ decreased considerably with little concomitant change in the specific activity of the RNA extracted from the heterogeneous non-neuronal fraction (Fig. 1b). This might be explained by migration of neuronal RNA into cellular compartments not recovered with the nerve cell bodies, such as axons and nerve endings. The corresponding increase in the

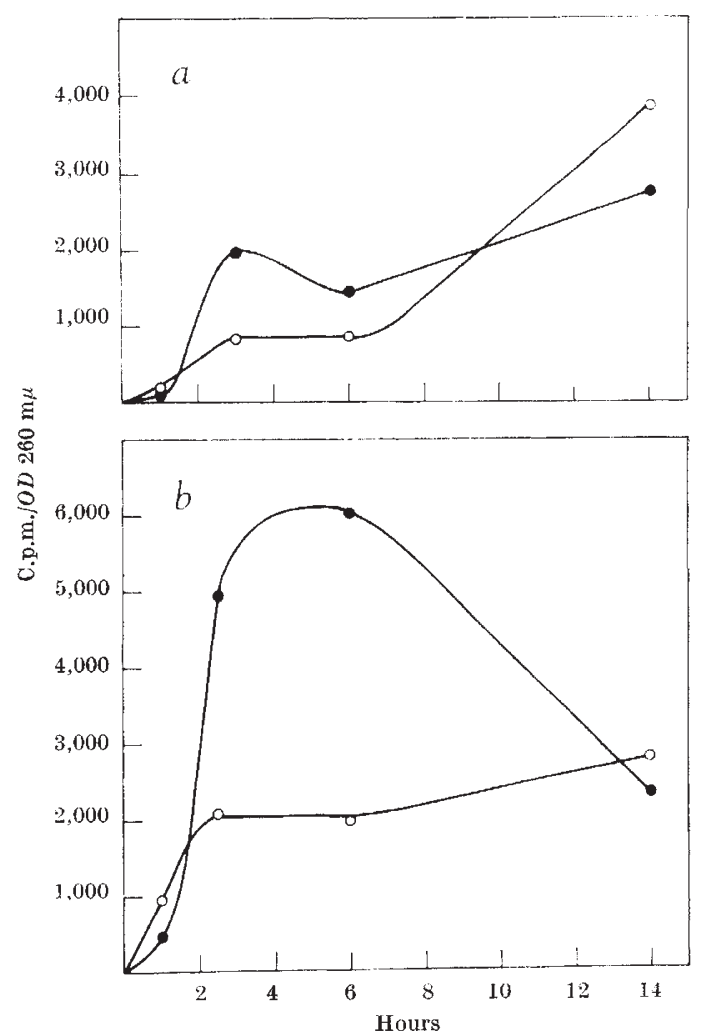

Fig. 1. Kinetics of labelling of total RNA in fractions enriched with neurones ( $)$ and neuroglia $(\odot)$. (a) Method of Rose; $(b)$ method of Satake integration of sucrose gradient patterns.

specific activity of neuroglial and to a smaller extent neuronal RNA prepared by the method of $\operatorname{Rose}^{1}$ (Fig. la) might reflect contamination of these fractions with such particulates.

P. VOLPE

A. Gruditta

International Laboratory of Genetics and Biophysics, Naples.

Received June 26, 1967.

1 Rose, S. P. R., Nature, 208, 621 (1965).

2 Satake, M., and Abe, S., J. Biochem. (Tokyo), 59, 72 (1966).

3 Vesco, C., and Giuditta, A., Biochim. Biophys. Acta, 142, 385 (1967).

- Attardi, G., Parnas, H., Hwang, M. I. H., and Attardi, B., J. Mol. Biol., 20, 145 (1966).

s Scherrer, K., Marcaud, I., Zajdela, W., London, I. M., and (Mros, F., Pro' US Nat, Acad. Sci., 56, 1571 (1966).

\section{Evidence for the Random Aggregation of Sub-units to produce Multiple Forms of Lactate Dehydrogenase in the Brains of Rat and Man}

LACTATE dehydrogenase (LDH) activity is present from the earliest stages of animal development and has been detected in the oocytes of both vertobrates ${ }^{1}$ and invertebrates ${ }^{2}$. It is now recognized that the enzyme is composed of two typos of sub-unit ${ }^{3}$, with separate structural genes ${ }^{4}$, which probably combine randomly ${ }^{5}$ into tetramors forming the five electrophoretically distinct forms, $\mathrm{H}_{4}, \mathrm{H}_{3} \mathrm{M}, \mathrm{H}_{2} \mathrm{M}_{2}$, $H M_{3}, M_{4}$. These have been numbered LDH-1 to 5 , respectively, with $\mathrm{LDH}-1$ being the most electropositivo.

The proportions of the LDH forms have been observed to change during the development of various tissues from rat $^{5}$, chick $^{6,7}$, rabbit $^{8}$ and human ${ }^{5,9}$, which suggests that the two structural genes are under independent although possibly linked control. Attention has been directed 